\title{
Origin and Connotation Analysis of Modern Supply Chain
}

\author{
Liu Xianli ${ }^{1,2, *}$, Li Yanfeng ${ }^{1}$ \\ ${ }^{1}$ School of Logistics, Yunnan University of Finance and Economics, Kunming, China \\ ${ }^{2}$ Dianchi College of Yunnan University, Kunming, China
}

Keywords: Traditional Supply Chain; Modern Supply Chain; Review

\begin{abstract}
Starting from the comparison between traditional supply chain and modern supply chain, the origin and concept of modern supply chain are gradually revealed in terms of time scope, market environment, operation mode, management mode, management responsibility and wisdom level. Further the paper illustrates the connotation of the modern supply chain from four aspects those are strategic positioning, production mode, achieving the goal and green development. Finally, the paper further conceived the definition of the connotation of modern supply chain, the deep integration of the Internet of Things, and the measurement of new kinetic energy in the modern economic system, and pointed out the direction for further exploration.
\end{abstract}

\section{Introduction}

In recent years, with the development of social division of labor, the promotion of information technology and the change of demand structure, supply chain has increasingly become an important force to promote social progress and industrial change. At the same time, the Party Central Committee and the State Council have paid high attention to the development of the supply chain and have issued a series of documents and policies on this field. On October 13th, 2017, the General Office of the State Council issued Document No.84 (Guiding Opinions of the General Office of the State Council on Actively Promoting Supply Chain Innovation and Application) which is the first time to make a comprehensive deployment on supply chain innovation and development ${ }^{[1]}$. General Secretary Xi Jinping clearly proposed in the 19th Party Congress report that new growth points should be cultivated in the field of modern supply chain, new momentum should be formed, and a modern economic system should be built ${ }^{[2]}$. This will greatly promote the development of China's supply chain to a modern supply chain. However, the research in this field is relatively scattered at present, especially in China. In view of this, this paper will systematically sort out the existing relevant research from the origin and connotation of modern supply chain, so as to clarify the research and development status quo and point out the direction for further exploration.

\section{Origin Modern Supply Chain}

The word "supply chain" can be traced back to "economic chain" and "value chain" ${ }^{[3]}$. Under the dual demand of market change and customer demand, "supply chain" came into being. Based on the viewpoints of experts and scholars such as Friedrich Hirth (2012), Ding Junfa (2017), Cao Derong (2017) and literature review, the development of "supply chain" can be roughly divided into two periods: traditional supply chain and modern supply chain ${ }^{[4-6]}$.

In the 1960s, it was the time when the idea of "economic chain" came into being, and it was also the time when the enterprise began to scientifically manage the internal material demand. Therefore, this time was taken as the starting time of the traditional supply chain. During the 12th Five-Year Plan period, as the dividing point between the traditional supply chain and the modern supply chain, it is mainly based on the consideration of management needs and the support of information technology. Compared with the last century, the management needs of enterprises at this stage have undergone great changes, requiring the emergence of large-scale personalized production methods. At the information foundation level, the Internet of Things, big data, cloud computing, block chains and other basic modes of production and management can support large-scale personalized 
production.

\subsection{Traditional supply chain (1960s-12th Five-Year Plan)}

The traditional supply chain can be considered as an integrative and collaborative system between various departments within an enterprise and between an enterprise and its external partners. It is a management science of an enterprise. Traditional supply chain management methods are generally reflected in logistics demand planning (MRP, 1960s), manufacturing resource planning (MRPII, 1970s), enterprise resource planning (ERP, 1980s), and supply chain management (SCM, 1990s).

In the 1980s, the market environment faced by enterprises changed dramatically: from the previous supplier-dominated, static and simple market environment to the current customerdominated, dynamic and complex market environment. At the same time, the development of infrastructure such as the Internet and its databases is relatively mature, making it possible for enterprises to realize system integration, resource integration and information sharing within the local area network. Therefore, the traditional supply chain management has also evolved from the integration of internal resources into the integration of enterprise and external resources. Its operation mode is one-way B2C (enterprise-to-customer) to achieve a certain link or partial optimization.

\subsection{Modern supply chain (12th Five-Year Plan-)}

Modern supply chain can be considered as a large-scale and efficient collaboration of enterprises crossing the time, space and network supported by modern information technology. It is a profound transformation of modern production mode, the latest trend of industrial and economic organization innovation, the micro foundation of modern economic system, and an important influencing factor of economic operation quality, efficiency, stability and safety. Modern supply chain management methods are mainly embodied in collaborative design and manufacturing, artificial intelligence industry supply chain based on big data and global supply chain applications.

During the "12th Five-Year Plan" and "13th Five-Year Plan", the market environment faced by enterprises has undergone tremendous changes: from the past customer-dominated, dynamic and complex market environment to the increasingly complicated production and the detailed and deepened division of labor in society. Large-scale supply chain coordination is needed to create new consumption space for the vast number of users from the supply side. At the same time, the progress and application of information technology (Internet, Internet of Things, big data, cloud computing, e-commerce and other technologies) make it possible for enterprises to realize the vertical and horizontal integration of upstream and downstream customers on the open platform, the flattening of supply chain organization and the popularization of virtual production, cloud manufacturing and other applications. Therefore, modern supply chain management has evolved from value chain collaboration to intelligent supply chain (big data support, network sharing, intelligent collaboration, document 84). Its operation mode is two-way C2C (customer-to-customer), realizing the overall and global optimization.

\section{Concept Modern Supply Chain}

\subsection{Traditional supply chain period}

It has roughly experienced three angles of logistics management, value added and network system.

The main point of view of logistics management is to basically study the logistics flow within the enterprise, mainly involving the process of production logistics within the enterprise, logistics transportation and storage within the factory area, sales logistics, and finally delivering products to consumers. The main point of view from the value-added perspective is to start to realize cooperation with other enterprises and pay attention to changes in the external environment. It refers to the supply and demand network composed of suppliers of raw materials and parts involved 
in the production and circulation of products, manufacturers of products, distributors of products, retailers of products and final consumers.

The main points of view of network system is basically to recognize that supply chain is a network system structure, and at the same time economic behaviors such as purchase, production and sales are also taken into account in this network system structure. Christy and Grout(1994) and Jayashankar M(1996) respectively elaborated on the supply chain from the perspective of a network system $^{[7-8]}$. Supply chain is a network tool that an enterprise starts from purchasing raw materials for the production of products, then carries out production within the enterprise, and finally sells to consumers through distributors and retailers.Beamon(1999), Ma Shihua (2000), Togar(2005) and other scholars further expanded the supply chain from the perspective of economic chain and core enterprises ${ }^{[9-11]}$. From the perspective of economic chain research, the main point of view is: in this economic chain, suppliers, manufacturers, distributors, retailers and consumers are combined together for common products and services ${ }^{[9]}$.From the perspective of core enterprise research, there is a leader enterprise (core enterprise) in the supply chain, and then around the common market, it starts with purchasing raw materials for producing products, then carries out production within the enterprise, and finally sells to consumers through distributors and retailers. A series of information flow, capital flow and logistics flow smoothly ${ }^{[10]}$.Togar(2005) believes that the supply chain is a network structure formed by various enterprises, which work together for the same kind or type of products and are responsible for production, procurement and sales respectively ${ }^{[11]}$.

\subsection{Modern Supply Chain Period}

Ma Shihua believes that the modern supply chain has four characteristics: global, personalized, flexible and digital. He advocates the concepts of resource integration, cooperative operation, supply-demand matching and benefit sharing. The competitiveness mode changes from singlehandedness to supply chain integration. Document No.84 (2017) holds that "the supply chain is an organizational form that takes customer demand as the orientation, improves quality and efficiency as the goal, and integrates resources as a means to realize efficient coordination in the whole process of product design, procurement, production, sales and service”. The "products" here should include physical products and service products. At the same time, the document also clearly states: "Build an intelligent supply chain system with big data support, network sharing and intelligent collaboration”. Obviously, this guiding ideology proposes that the core elements of China's modern supply chain innovation lie in perception (meaning information digitization), interconnection (meaning subject ecology) and service (meaning process element integration).The combination of the above three elements will build the supply chain into a smart community with "human" characteristics. This paper adopts document 84 to define modern supply chain.

\section{Connotation of Modern Supply Chain}

The connotation of modern supply chain is mainly understood from four aspects (Cai Jin (2017) ${ }^{[12]}$ and Ding Junfa (2017) ${ }^{[5]}$ ), such as strategic positioning, production mode, target realization and green development, as shown in Table 1.

\subsection{Strategic Positioning}

The two periods of traditional supply chain and modern supply chain have different strategic positioning. The former is mainly based on microscopic thinking and focuses on scientific management of businesses related to material flow within and between enterprises. The latter enlarges the perspective of supply chain research, not only focusing on scientific management of enterprises, but also more on scientific urban supply chain and strategic global supply chain. At the same time, it further clarifies the important position of modern supply chain in the national economy for a long time now or even in the future. Modern supply chains provide new growth points and create new momentum for the development of the national economy. 


\subsection{Production mode}

Traditional supply chain and modern supply chain have different modes of production in the two periods. The former is mainly demand-driven, with customers putting forward demand orders, which are then sequentially transmitted by retailers, distributors, manufacturers and suppliers to produce in the manufacturing enterprise. During this period, the integration level among enterprises was relatively high, and the logistics costs of production, transportation and storage were relatively high, so it was urgent to realize large-scale personalized production. The latter is mainly supplydriven, with manufacturers and relevant alliance partners providing new products or services, especially physical products, to consumers. The key is not only to use the product as a consumer, but also whether businesses can tap other potential market values based on the product through the use of the product by consumers. For example, mobile phones can not only realize the use value, but also can be based on the real mobile payment of smart phones, sharing bicycles and other business models.

\subsection{Target realization}

The two periods of traditional supply chain and modern supply chain have different goals. The former is mainly to reduce costs and improve efficiency for the existing stock, thus to maintain the core competitiveness in the industry and to improve the operation quality of enterprises. The latter is mainly to transform the supply system to create new value, new wealth and new momentum, so as to maintain the core competitiveness in the industry, the region and even the world and to improve the operation quality of enterprises, cities and countries.

\subsection{Green development}

In the traditional supply chain period, the development focuses on quantity and speed, which belongs to extensive development. At the same time, the awareness of green development is not strong and the attention to it is not enough. During the modern supply chain period, attention is paid to development quality and development benefits, which is fine-grained development. At the same time, the awareness of green development was strong. Modern information technology could also be used to build a green supply chain system with all processes, links and elements.

Table 1 Difference between Traditional Supply Chain and Modern Supply Chain

\begin{tabular}{|c|c|c|c|}
\hline \multicolumn{2}{|r|}{ Difference } & Traditional Supply Chain & Modern Supply Chain \\
\hline \multirow{7}{*}{$\begin{array}{l}\text { Ideological } \\
\text { Evolution }\end{array}$} & Time Range & 1960s-12th Five-Year Plan & 12th Five-Year Plan period- \\
\hline & Technical Support & Local area network system & Open platform \\
\hline & CollaborationScope & Linear single chain coordination & Large-scale Network Chain Collaboration \\
\hline & Operation Mode & B2C, one-way & C2C, two-way \\
\hline & Management Style & MRP/MRPII/ERP/SCM & $\begin{array}{l}\text { Value Chain Collaboration, Smart Supply } \\
\text { Chain }\end{array}$ \\
\hline & Management Responsibility & PartOptimization & Global Optimization \\
\hline & Wisdom Degree & Degree of intelligence is not high & Degree of automation has increased \\
\hline \multirow{4}{*}{$\begin{array}{l}\text { Characteristic } \\
\text { Connotation }\end{array}$} & Strategic Positioning & $\begin{array}{c}\text { Micro Enterprises Management } \\
\text { Science }\end{array}$ & National Economy, New Kinetic Energy \\
\hline & Production Mode & Demand-driven & Supply drive \\
\hline & Achieve Goal & $\begin{array}{l}\text { Cost reduction and efficiency } \\
\text { improvement for existing stocks }\end{array}$ & $\begin{array}{l}\text { Reforming Supply System to Create New } \\
\text { Value, New Wealth, New Kinetic Energy }\end{array}$ \\
\hline & GreenDevelopment & $\begin{array}{l}\text { Green and low-carbon development } \\
\text { is not given enough attention. }\end{array}$ & $\begin{array}{l}\text { Green Supply Chain System of Whole } \\
\text { Process, Whole Link and Whole Element }\end{array}$ \\
\hline
\end{tabular}

\section{Summary}

Under the background of document No.84 and modern supply chain, this paper systematically 
compares modern supply chain with traditional supply chain, as shown in table 1 . Then it reveals the connotation and concept of modern supply chain. Based on the existing research, the following issues need further consideration.

1. The connotation and definition of modern supply chain need to be further defined. What is the difference between modern supply chain and intelligent supply chain? What kind of new ideas, new technologies and new models of modern supply chain have? The research on such basic problems needs to be further studied.

2. The deep integration of modern supply chain with Internet and Internet of Things, especially with Internet of Things, needs further research. How to measure of the integration degrees of the two? How to integrate? What is the path of integration? How does deep integration affect industry development? Such problems need to be further studied.

3. General Secretary Xi Jinping has made it clear: Cultivate new growth points and form new momentum in the field of modern supply chain. How does the modern supply chain provide new momentum in the modern economic system? What method is used for research? How to measure the new momentum? How to Measure the impact of modern supply chain on economy? Such problems need to be further studied.

\section{Acknowledgements}

This paper is one of the phased achievements of Yunnan Social Science Fund youth project "statistical measurement and effect research on the development level of cross-border e-commerce in Yunnan" (QN2018010).

\section{References}

[1] General Office of the State Council. Guidance of General Office of the State Council on Actively Promoting Supply Chain Innovation and Application [EB/OL]. [2017-10-13]. http://www.gov.cn/Zheng ce/content/2017-10/13/content_ 5231524.htm?trs=1.

[2] Xi Jinping. Report made at the 19th National Congress of the Communist Party of China "Deciding to Build a Well-to-do Society in an All-round Way and Seize the Great Victory of Socialism with Chinese Characteristics in the New Era" booklet [M]. Beijing: People's Publishing House, October 18, 2017: 30-31.

[3] Michael Porter. Competitive Advantage [M]. Beijing: Huaxia Publishing House, 1997: 33-53.

[4] Friedrich Hirth. Mass Customization Supply Chain Operation Mechanism and Strategy [M]. Beijing: China Economic Publishing House, April 2012.

[5] Ding Junfa. Wan Networking: Interpretation of Supply Chain Innovation New Deal [EB/OL]. [2017-10-24]. http://info.10000link.com/OpinionDetail.aspx?doc=2017102590014.

[6] Cao Derong. Xinhua: China's supply chain has entered a new stage of modern supply chain development [EB/OL]. [2017-11-13]. http://www.xinhuanet.com/interview/2017-11/13/c _ 1121949123.htm

[7] Christy D.P. Grout J.R. Safeguarding supply chain relationships [J]. International Journal of Production Economics. 1994(36): 233-242.

[8] Jayashankar M. Swaminathan, Stephen F. Smith, Norman M. Koniecpol.A Multi Agent Framework for Modeling Supply Chain Dynamics[R].TechnicalReport,The Robotics Institute, Carnegie Mellon University,1996.

[9] Beamon B. M. Measuring Supply Chain Performance [J].InternationalJournal of Operations and Production Management, 1999;19(3):275-292.

[10] Ma Shihua, Lin Yong, Chen Zhixiang. Supply Chain Management [M]. Beijing: Machinery Industry Press, 2000. 
[11] Togar M. Simatupang, RamaswamiSridharan. The collaborationindex:a measure for supply chain collaboration[J].International Journal of Physical Distribution\&Logistics Management, 2005(35): :44-62.

[12] Cai Jin. Wan Networking: Promoting Innovative Development of Modern Supply Chain [EB/OL]. [2017-11-24]. http://info.10000 link.com/newsdetail.aspx?doc=2017112490010. 